\title{
IMIGRAÇÃO E DIREITOS HUMANOS - LEGISLAÇÃO E POLÍTICAS PÚBLICAS - REFLEXOS NAS SERVENTIAS EXTRAJUDICIAIS
}

\section{Marilia Reato Silva de Sousa*}

\section{RESUMO}

O presente artigo analisa a questão da imigração em face da soberania dos Estados e da atual doutrina e legislação acerca dos direitos humanos no Brasil e no mundo. Aponta incongruências entre a legislação de direitos humanos vigente e as políticas públicas excludentes ainda hoje aplicadas aos imigrantes, tomando como exemplo as normas aplicáveis às serventias extrajudiciais. Trata da necessidade de revisão e readequação de normas internas e de políticas públicas para maior inclusão do imigrante e aponta seus potenciais efeitos benéficos para o Estado receptor.

Palavras chave: imigração - direitos humanos - soberania do Estado - políticas públicas serventias extrajudiciais

\section{IMMIGRATION AND HUMAN RIGHTS -LAW AND PUBLIC POLITICS - REPERCUSSIONS ON NOTARY AND REGISTRY'S OFFICES}

\begin{abstract}
This paper analyses the immigration in face of the Estate's sovereignty and the current human rights doctrine and law in Brazil and in the world. It indicates the incongruity between human rights in force law and excluding public policies still applied to immigrants, taking as example the law applicable to notary and registry's offices. It approaches the need of revision and readjustment of internal law and public policies to include the immigrant and indicates the potential beneficial effects to the receiving Estate.
\end{abstract}

Keywords: immigration - human rights - Estate's sovereignty - public policies - notary and registry's offices

\section{INTRODUÇÃO}

Esse artigo visa analisar a questão dos imigrantes, em especial aqueles que denominamos como "imigrantes de fato" e sua inclusão nos Estados que os recebem.

O objetivo é contribuir para a revisão dos paradigmas de preconceito com relação ao imigrante advindo de políticas excludentes dos Estados soberanos. Para isso, será analisada a relação do Estado receptor com o imigrante, em especial aquele marginalizado e vulnerável, diante do panorama internacional de direitos humanos e dos princípios e valores da Constituição Federal de 1988. A partir daí, e identificadas as violações de direitos, pretendese elucidar algumas políticas excludentes que atualmente ainda estão em vigor e apontar que

\footnotetext{
*Tabeliã de Notas na cidade de Ribeirão Preto-SP, Mestranda na Faculdade de Direito de Ribeirão Preto da Universidade de São Paulo, Pós-Graduada em Direito Constitucional, Direito Civil e Direito Notarial e Registral, Graduada pela Faculdade de Direito da Universidade de São Paulo. Endereço eletrônico: mariliareato@usp.br.
} 
tais políticas não fazem mais sentido no Século XXI, especialmente em face da evolução do entendimento sobre direitos humanos e das evidências de seu caráter desagregador, não apenas para o desenvolvimento do Estado receptor, mas também da civilização humana de modo geral.

Para isso parte-se de uma análise do Estado soberano e de sua relação com aquelas pessoas que cruzam as suas fronteiras, objeto do segundo item. A seguir, procura-se delimitar quem é o imigrante vulnerável às políticas excludentes do Estado, o "imigrante de fato", objeto do terceiro item. Em seu quarto item trata dos direitos humanos, da evolução da doutrina e legislação internacionais sobre o assunto após a $2^{\mathrm{a}}$ Guerra Mundial, e da inserção dos imigrantes nesse contexto. A seguir, em seu quinto item, traz um panorama da legislação brasileira sobre o assunto. No sexto item trata do exercício de direitos pelos imigrantes, mais especificadamente do papel das serventias extrajudiciais nesse contexto para, enfim, tecer os pontos conclusivos em seu sétimo e último item.

\section{O ESTADO E OS IMIGRANTES}

É sabido que o mundo de hoje é dividido em Estados soberanos. E segundo a Convenção Pan-Americana sobre Direitos e Deveres dos Estados (Montevidéu, 1933, ratificada no Brasil pelo Decreto 1.570/1937) (“Convenção de Montevidéu”) o Estado é pessoa de direito internacional, desde que obedeça aos seguintes requisitos: a) povoação permanente; b) território determinado; c) governo; d) capacidade de entrar em relações com os demais Estados. Ainda, estabelece a Convenção de Montevidéu que "os Estados são juridicamente iguais, desfrutam iguais direitos e possuem capacidade igual para exercê-los. Os direitos de cada um não dependem do poder de que disponha para assegurar seu exercício, mas do simples fato de sua existência como pessoa de Direito Internacional." (artigo $4^{\circ}$ ).

Sobre a autonomia dos Estados, especialmente no quesito imigrações, aponta REIS:

[...] não existe nenhuma organização superior ao Estado neste aspecto específico que possa obriga-lo a aceitar quem quer que seja em seu território. A autonomia do Estado no campo das migrações é uma das principais características do direito internacional tradicional. (REIS, 2004, P. 150) 
Assim, no mundo de hoje vivemos sob a égide de Estados que exercem sua soberania dentro de suas fronteiras, regulando, entre outras coisas, a entrada e saída de pessoas de seus limites territoriais, ou seja, a chamada migração internacional. É por essa razão que as pessoas precisam, no mundo atual, de passaportes e, muitas vezes, de vistos válidos para cruzar as fronteiras dos países. Inclusive, esse "monopólio de legitimidade da mobilidade é considerado um dos fundamentos da soberania do Estado" (REIS, 2004, p.150).

Nesse contexto, a migração internacional é inteiramente regulada pelos Estados, que possuem autonomia total para determinar quem pode ou não migrar para o seu território. E mais do que o monopólio sobre a mobilidade, os Estados também têm controle sobre a própria identidade do indivíduo, sua nacionalidade, que quase sempre é atribuída a ele independentemente de sua vontade. Nesse sentido, o acesso aos direitos de cidadania está condicionado à posse da nacionalidade (REIS, 2004). E como é o Estado que determina quais são os direitos exclusivos dos cidadãos, por consequência, também determina os direitos inacessíveis aos imigrantes. Isso, como se verá no decorrer deste artigo, é uma porta a políticas públicas excludentes, o que viola doutrina e legislação de direitos humanos atualmente vigentes.

\section{DO IMIGRANTE}

Mas quem, afinal, é o imigrante? Segundo REIS (2004), para se determinar quem é o imigrante é preciso determinar quem é o cidadão, pois as políticas de nacionalidade e imigração estão intimamente ligadas. Por essa lógica, em regra, qualquer um que não seja um cidadão de um determinado Estado, mas que se encontra em seu território, é um imigrante.

Ocorre que, inevitavelmente, as políticas de imigração refletem interesses econômicos, demográficos e conjunturas políticas de um determinado Estado soberano, que continua regulamentando essa questão tendo em vista seus interesses específicos. Assim, determinados imigrantes podem ser interessantes para um Estado e ter sua entrada e convivência social facilitadas, enquanto outros, ao contrário, são marginalizados e tratados como um problema de segurança pública e de polícia.

E é com essa realidade em vista que, para fins desse artigo, o imigrante a que nos referimos nem sequer precisa ser imigrante propriamente dito. Pode até ser um nacional de família de imigrantes ou alguém que adquiriu a cidadania, mas que permanece imigrante de fato. Mas então, quem seria esse "imigrante de fato"? 
O imigrante de fato é aquele que "representa uma diferença cultural que afronta o mito da homogeneidade do Estado - nação" (VELASCO, 2014, P. 25). Os imigrantes são, portanto, "indivíduos que, mais do que não nacionais, mantêm uma dependência da sociedade de imigração, uma condição social que os transforma em mera força de trabalho, com uma função social que despolitiza o tema da imigração.” (VELASCO, 2014, P. 25)

O imigrante de que tratamos nesse artigo não é, portanto, o rico. É o pobre marginalizado e visto como mera força de trabalho. Imigração aqui é vista "como um sistema social, que se mantém por uma relação de dominação - ainda que simbólica - entre o país de imigração e o país de emigração." (SAYAD, 2004, P. 162-163, in VELASCO, 2014, P. 26). Assim, segundo VELASCO:

O imigrante é de fato imigrante quando é despido - e se despe - da atribuição de cidadão - com voz política - e passa a ser apenas uma força de trabalho, razão de seu deslocamento. E é somente como força de trabalho que a sociedade de imigração aceita sua permanência supostamente temporária. Não se trata, entretanto, de qualquer tipo de trabalho. O emigrante-imigrante é um trabalhador não qualificado, que, para sobreviver, não tem outra saída a não ser se submeter à condição de dominação das relações de trabalho esteja ele irregular ou não no país (SAYAD, 2004, P.162-176).

\section{$[\ldots]$}

O objetivo é se pensar, em termos históricos e sociológicos, como o discurso sobre a imigração está intrinsecamente vinculado a sua constituição em um sistema de hierarquias sociais e como esse sistema está implicado nas medidas de segurança que hoje afetam os imigrantes, não apenas nas fronteiras territoriais, mas também nas exclusões cotidianas, mesmo que eles já estejam legalmente permitidos a pertencer à comunidade política. (VELASCO, 2014, P.26-28)

Assim, o imigrante ao qual nos referimos neste artigo, o imigrante de fato, é aquele que para o Estado, tendo em vista seus interesses econômicos e demográficos, é visto como 
mera força de trabalho barato, ou como uma inconveniência, sendo alvo de políticas públicas que favorecem a desigualdade, a discriminação e a exclusão. O imigrante é, portanto, uma pessoa que se encontra fora de seu país de origem, a quem por muitas vezes são negados direitos básicos relacionados à cidadania, e a quem são dirigidas políticas públicas excludentes e até criminalizantes.

\section{DIREITOS HUMANOS E OS DIREITOS DOS IMIGRANTES}

A doutrina e os tratados internacionais que regulam direitos humanos passaram por uma imensa evolução ao longo dos últimos anos, em especial após a $2^{\mathrm{a}}$ Guerra Mundial. Nessa realidade pós-guerra, podem ser destacados três grandes tratados envolvendo direitos humanos: a Declaração Universal dos Direitos Humanos, de 1948; o Pacto Internacional sobre Direitos Civis e Políticos e o Pacto Internacional sobre Direitos Econômicos, Sociais e Culturais, ambos de 1966. Em conjunto, esses três pactos resumem a estrutura normativa básica dos direitos humanos no mundo pós-guerra.

Esses tratados refletem um consenso mundial de que o ser humano é detentor de direitos fundamentais, inerentes à sua condição, e que tais direitos precisam ser reconhecidos e respeitados para que a todos seja garantida uma existência digna. Por essa razão que esses tratados garantem direitos que hoje são tidos como básicos do ser humano, como os direitos à vida, à liberdade, a não submissão à tortura e à escravidão; além de direitos tidos como sociais, como o direito ao trabalho, à moradia, à alimentação, entre outros.

Sobre esses direitos, cumpre mencionar rapidamente que a doutrina especializada os divide em três tipos, ou gerações. Assim, temos a primeira geração, que trata de direitos relacionados à liberdade, a segunda geração, com direitos relacionados à igualdade, e a terceira geração, com direitos relacionados à fraternidade.

Os direitos chamados de primeira geração são direitos "negativos", pois se referem à imposição de limites ao poder do Estado, de forma a garantir liberdades aos seus cidadãos. São os direitos civis e políticos e possuem caráter individual. Já os direitos de segunda geração, chamados de direitos sociais, econômicos e culturais, possuem titularidade coletiva e um caráter "positivo", pois exigem a atuação do Estado para serem cumpridos (ex: direito à educação, saúde, etc.). Finalmente, os direitos de terceira geração são relacionados ao 
desenvolvimento e progresso, ao meio ambiente, à autodeterminação dos povos. São direitos transindividuais, destinados à proteção do gênero humano como um todo. ${ }^{1}$

E foi nesse contexto internacional, com a política do pós $2^{\mathrm{a}}$ Guerra Mundial e a doutrina sobre direitos humanos evoluindo, que se percebeu que os tratados internacionais até então existentes não bastavam para garantir todos os direitos inerentes ao ser humano no âmbito das três gerações ou dimensões acima mencionadas.

Dessa forma, foram celebrados outros acordos internacionais que envolvem direitos humanos. Com relação aos imigrantes, tais tratados abordaram, mais especificamente, os direitos dos refugiados e dos apátridas. Assim, em 1951 foi assinada em Genebra a Convenção Relativa ao Status de Refugiado ("Convenção de Genebra”); em 1954 a Convenção Relativa aos Apátridas; em 1961 a Convenção de Prevenção da Formação de Apátridas; e em 1967, em Nova York, o Protocolo de Refugiados. Sobre tais convenções, REIS:

A Convenção Relativa ao Status de Refugiado foi assinada em 1951, na cidade de Genebra, e tinha um âmbito bastante limitado e preciso, qual seja, a situação das pessoas deslocadas pelos regimes totalitários da Europa nos anos de 1930 e pela Segunda Guerra Mundial. Em 1954, surgiu a Convenção Relativa aos Apátridas, que também se referia basicamente a situações do pós-guerra. No entanto, com a persistência dos conflitos armados e das ditaduras nos anos subsequentes, esses mecanismos foram sendo estendidos $e$ aperfeiçoados para dar conta das novas situações. Em 1961, foi assinada a Convenção de Prevenção da Formação de Apátridas, e, em 1967, o Protocolo de Refugiados, em Nova York, o qual estendeu o conceito de refugiados para outros tipos de situação.

A Convenção de Genebra prevê, entre outras coisas, que os Estados signatários têm obrigação de analisar os pedidos de asilo e de conceder aos refugiados o mesmo tratamento de que usufruem os cidadãos do país no que concerne à educação, à saúde e às condições

\footnotetext{
${ }^{1}$ Importante mencionar que a doutrina ainda fala de direitos de quarta e até quinta geração, mas ainda não há consenso de sua existência ou mesmo de seu conteúdo, assim, e tendo em vista o objeto principal deste artigo, deixaremos de tratar desse assunto nesse momento.
} 
de emprego. Além disso, deve-se garantir que não haja discriminação e que não sejam penalizados mesmo os candidatos a asilo que entrarem em um país sem autorização. [...]

A Convenção sobre os Apátridas de 1954 afirma basicamente que os indivíduos não considerados cidadãos nacionais por nenhum país devem ter seus direitos garantidos pelo Estado no qual residem, o qual deve também ser responsável pela emissão de documentos de identidade, além de facilitar o processo de naturalização. A Convenção de 1961 trata da prevenção da formação de apátridas, comprometendo os Estados signatários a concederem a nacionalidade a pessoas que nasceram em seu território ou aqueles nascidos em outro território, cujos pais sejam "nacionais" desse Estado, e que, de outra forma, se tornariam apátridas; e também a não punirem com a perda da nacionalidade os casos de mudança de status, como casamento, divórcio, adoção ou aquisição de outra nacionalidade. (REIS, 2004, p. 151)

Contudo, o que se depreende é que apesar de garantir alguns direitos a migrantes internacionais, tais convenções são extremamente limitadas, pois somente se aplicam a casos de refugiados e apátridas. Além disso se baseiam em uma lógica de exceção, ou seja, somente alguns direitos são concedidos, e em casos bem específicos, sempre respeitando a soberania dos Estados. Assim,

[...] nenhum Estado é obrigado a acolher os refugiados, apenas são proibidos de mandá-los de volta aos países acusados de perseguição (princípio de non-refoulement). Também não existe nenhum organismo supranacional capaz de controlar ou de punir os Estados que infringirem a lei" (BHABHA, 1998; MBAYA, 1998, in REIS, 2004, p. 151).

Dessa forma, ainda que as convenções sobre direitos humanos mencionadas garantam direitos aos imigrantes, seu âmbito de atuação é extremamente limitado. Assim, 
formou-se um consenso de que a os tratados existentes não eram suficientes para lidar com as questões decorrentes das relações dos Estados com indivíduos estrangeiros (REIS, 2004). Pois se por um lado a questão da migração internacional é tida como assunto relacionado à soberania de cada Estado; por outro, há a questão dos direitos que esses imigrantes, como seres humanos, possuem e que devem ser respeitados.

Esse é um desafio que os Estados em todo o mundo enfrentam diariamente, e que tem sido cada vez mais difícil e delicado, tendo em vista o número crescente de refugiados em todo o planeta, como aponta REIS:

$O$ fortalecimento de um regime internacional de direitos humanos, segundo essas novas pesquisas, tem obrigado os Estados a redefinirem suas fronteiras, tanto a interna como a externa, em função da universalidade dos direitos individuais. Esse processo possuiria duas características: de um lado, os Estados estariam vendo sua soberania enfraquecida frente ao indivíduo, de outro, os laços que ligam os direitos de cidadania à nacionalidade estariam se tornando mais fracos. Isso significa, entre outras coisas, que o Estado não seria mais capaz de definir, em função de seus próprios interesses, quem pode ou não entrar e se estabelecer em seu território, e, ainda, que cada vez mais os direitos são atribuídos em nome da dignidade inerente da pessoa humana, e não da sua nacionalidade, de modo que a própria distinção entre nacional e não nacional estaria perdendo sua importância.

A criação de um regime internacional de direitos humanos estaria, pois, levando a uma perda de autonomia do Estado na tarefa de decidir sobre questões referentes ao direito de entrada, ao tipo de diferenciação entre nacionais e estrangeiros dentro de seu território, ao direito de residência permanente e aos critérios de nacionalização. (REIS, 2004, P. 157)

E foi diante dessa realidade que uma série de novos tratados foram assinados, entre eles a Convenção sobre Direitos dos Imigrantes, aprovada na Assembleia Geral da ONU em 
1990. Entre outras coisas, essa Convenção sobre Direitos dos Imigrantes exige (i) o mesmo tratamento no âmbito do trabalho para cidadãos nacionais e imigrantes legais, (ii) que estes sejam informados sobre os seus direitos numa língua que compreendam; e (iii) que possam recorrer ao Judiciário em caso de deportação.

Contudo, seu número mínimo de ratificações demorou para ser atingido, tendo entrado em vigor apenas em 01/07/2003, e sem a assinatura dos principais países receptores de imigrantes, inclusive do Brasil, o que restringe, e muito, sua efetiva aplicação. Além disso, outro grande problema está na questão dos imigrantes não documentados, situação não protegida por tratados internacionais específicos, o que os deixa "duplamente" desprotegidos: primeiro pela situação de imigrante por si só, segundo pela falta dos documentos de imigração.

Assim, apesar de toda a evolução doutrinária e legislativa no tratamento de imigrantes como indivíduos detentores de direitos, na prática o que se vê é que os imigrantes continuam marginalizados. Se por um lado os Estados estão sendo obrigados a abdicar de parte de sua soberania em prol de direitos humanos, por outro, uma vez dentro de um Estado, o imigrante se vê sujeito a políticas públicas discriminantes, a situações de vulnerabilidade, em que seus direitos, para se efetivarem, dependem de ações que os Estados não parecem interessados em implementar. Nesse sentido, REIS:

[...] o estudo da evolução do regime internacional de direitos humanos nos mostra que, apesar do crescente reconhecimento do indivíduo como portador de direitos independentes de sua nacionalidade, a implementação desses direitos continua basicamente dependente do Estado, e, no caso específico das migrações internacionais, do Estado receptor.

\section{$[\ldots]$}

Cidadania significa, acima de tudo, igualdade perante a lei e igualdade de acesso aos direitos, e, definitivamente, não há, sob esses aspectos, nenhuma identidade entre imigrantes $e$ cidadãos “nacionais". O fato de os estrangeiros gozarem de um maior número de direitos hoje não modifica a natureza da cidadania. $O$ estrangeiro 
continua numa situação precária em relação ao cidadão. (REIS, 2004, P. 159)

O que se vê, portanto, é que na prática a questão das fronteiras e da soberania dos Estados permanece inatingível, incontestável. Isso gera uma incongruência entre doutrina/tratados de direitos humanos e prática/legislação dos Estados receptores, de forma a manter o imigrante de fato excluído e marginalizado dentro do Estado receptor, o que, como se verá a seguir, também ocorre no Brasil.

\section{PANORAMA DA LEGISLAÇÃO BRASILEIRA SOBRE IMIGRAÇÃO}

Nesse item será analisada a legislação brasileira sobre imigração, de forma a atestar que o Brasil não é diferente de outros Estados soberanos: aqui também, apesar de toda a evolução, a soberania e a autonomia do Estado permanecem intactas em face dos direitos dos imigrantes.

O Brasil, como um sujeito de direito internacional, um Estado soberano, possui todo um arcabouço normativo, seja nacional, seja internacional, que abrange os direitos dos imigrantes. Importante mencionar que, frente ao sistema internacional de proteção aos direitos humanos o Brasil, como aponta PIOVESAN:

[...] tão somente a partir do processo de democratização do país, deflagrado em 1985, é que o Estado Brasileiro passou a ratificar relevantes tratados internacionais de direitos humanos. [...]

Assim, a partir da Carta de 1988 foram ratificados pelo Brasil: a) a Convenção Interamericana para Prevenir e Punir a Tortura, em 20 de julho de 1989; b) a Convenção sobre os Direitos da Criança, em 24 de setembro de 1990; c) o Pacto Internacional dos Direitos Civis e Políticos, em 24 de janeiro de 1992; d) o Pacto Internacional dos Direitos Econômicos, Sociais e Culturais, em 24 de janeiro de 1992; e) a Convenção Americana de Direitos Humanos, em 25 de setembro de 1992; f) a Convenção Interamericana para Prevenir, Punir e Erradicar a Violência contra a Mulher, em 27 de novembro de 1995. 
As inovações introduzidas pela Carta de 1988 especialmente no que tange ao primado da prevalência dos direitos humanos, como princípio orientador das relações internacionais — foram fundamentais para a ratificação destes importantes instrumentos de proteção dos direitos humanos.

Além das inovações constitucionais, como importante fator para a ratificação destes tratados internacionais, acrescente-se a necessidade do Estado brasileiro de reorganizar sua agenda internacional, de modo mais condizente com as transformações internas decorrentes do processo de democratização. Este esforço se conjuga com o objetivo de compor uma imagem mais positiva do Estado brasileiro no contexto internacional, como país respeitador e garantidor dos direitos humanos. Adicione-se que a adesão do Brasil aos tratados internacionais de direitos humanos simboliza ainda o aceite do Brasil para com a idéia contemporânea de globalização dos direitos humanos, bem como para com a idéia da legitimidade das preocupações da comunidade internacional no tocante à matéria. Por fim, é de se acrescer o elevado grau de universalidade destes instrumentos que contam com significativa adesão dos demais Estados integrantes da ordem internacional. (PIOVESAN, 1997, p. 23)

Dessa forma, pelo que se vê a redemocratização brasileira e a promulgação da Constituição Federal de 1988 foram fundamentais para a retificação de tratados internacionais de direitos humanos. E, realmente, isso nada mais é do que cumprimento da diretriz constitucional, que em seu artigo $1^{\circ}$ estabelece como fundamento da República Federativa do Brasil a dignidade da pessoa humana, e em seu art. $4^{\circ}$ elege a prevalência dos direitos humanos como um dos princípios que regem suas relações internacionais.

Todavia, ainda que se reconheça a evolução do Brasil na seara dos direitos humanos após a redemocratização, na prática ainda há um longo caminho a ser percorrido para que o respeito aos direitos humanos realmente seja efetivo, em especial no que tange ao imigrante, a exemplo da não ratificação da Convenção sobre Direitos dos Imigrantes, acima mencionada. 
Outro exemplo disso é que até novembro de 2017 a legislação brasileira sobre imigrantes era retrógrada e violadora dos direitos desse segmento da população enquanto seres humanos. Isso porque a Lei 6.815, de 19 de agosto de 1980 (oriunda do regime militar, mas em vigor até 2017), tratava os imigrantes mais como um problema de segurança nacional do que como sujeitos de direitos, sendo um reflexo da questão complexa que é a relação entre direitos humanos e soberania do Estado, já apontada anteriormente.

E ainda que em 24 de maio de 2017 tenha sido promulgada a nova lei dos imigrantes, a Lei n. 13.445 (que entrou em vigor em 21 de novembro de 2017), na prática ao que tudo indica não haverá grandes mudanças. Quando de sua promulgação, referida lei foi tida como uma evolução no tratamento dos imigrantes no Brasil, pois os previu como sujeitos de direitos, diferentemente da legislação anterior. Contudo, apesar disso, seu decreto regulamentador está sendo duramente criticado, justamente por manter a filosofia da legislação anterior de tratamento do imigrante como problema de segurança nacional, com vários dispositivos contrários à própria lei, como alegado por algumas ONGs especializadas e pela própria Defensoria Pública da União. Nesse sentido:

Quando a lei foi sancionada, com vetos, pelo presidente Michel Temer, em maio deste ano, o texto foi bem recebido por organizações de defesa dos direitos humanos, uma vez que fora elaborado durante vários anos em conjunto com representações da sociedade civil e contempla princípios como a não-discriminação, o combate à homofobia e a igualdade de direitos de trabalhadores imigrantes e nacionais. Um dos princípios contidos na lei, por exemplo, é a "não discriminação em razão dos critérios ou dos procedimentos pelos quais a pessoa foi admitida em território nacional".

Mas também nesta terça-feira será publicado o decreto de regulamentação da nova lei. Esse dispositivo jurídico é expedido pelo chefe do Executivo e explica a lei e como ela deve ser aplicada.

$O$ decreto regulamentar não pode contrariar a lei, mas justamente essa crítica está sendo feita ao presidente por diversas organizações de defesa dos direitos dos migrantes, assim como pela 
Defensoria Pública da União (DPU). "O decreto tem aspectos claramente contrários à própria Lei de Migração, como a previsão de prisão do migrante que será deportado, quando o artigo 123 da lei expressamente proíbe privação de liberdade por razões migratórias", declarou Camila Asano, coordenadora de Programas da Conectas Direitos Humanos, à Folha de S. Paulo.

A DPU considera temas sensíveis "a concessão de vistos, o acesso a serviços e programas sociais e a maior participação dos migrantes nas decisões sobre política migratória no Brasil", segundo conclusão de um encontro que, em agosto, discutiu a regulamentação da nova lei.

Isso coloca mais uma vez em pauta a já mencionada questão da relação das políticas migratórias excludentes que geram as desigualdades enfrentadas pelos imigrantes ou, mais especificamente, pelo "imigrante de fato". A despeito de todos os tratados, da norma constitucional e, agora, da própria Lei 13.445/2017; ainda se praticam no Brasil políticas públicas discriminatórias, que dificultam a integração dos imigrantes, em especial dos não documentados.

Assim, mesmo que o Brasil tenha dado um passo à frente com a nova legislação, ainda há muito que fazer para efetivamente se garantir o respeito aos direitos dos imigrantes enquanto seres humanos. Naturalmente, com uma legislação tão recente, há que se esperar e verificar sua efetiva aplicação antes que se expresse qualquer conclusão definitiva. Ademais, um regulamento tão recente pode, ainda, sofrer diversos ajustes no futuro. De qualquer forma, o que se espera é que o espírito da lei, esse sim mais inclusivo que o regime anterior, seja respeitado, se não por razões humanitárias, por ser mais condizente com a ordem constitucional de 1988.

Todavia, como já mencionado, pior do que a situação do imigrante regular ou do refugiado, é a situação do imigrante irregular ou não documentado. Se os outros dois são protegidos pelo direito internacional e pátrio, o terceiro não tem qualquer rede de proteção específica e pode contar, no máximo, com a doutrina geral de direitos humanos que, como visto, não é o bastante. 
Assim, o que se vê é que apesar de todo o esforço normativo, o Brasil ainda tem políticas públicas excludentes em relação aos imigrantes de fato, em especial aos não documentados. Isso pode ser verificado não só pelo exposto acima, mas também pela legislação esparsa que ainda adota a filosofia de que o imigrante é uma questão de segurança pública e de polícia. Exemplo disso são as restrições que os imigrantes possuem para a prática de atos notariais e registrais, como se verá adiante.

\section{EXERCÍCIO DOS DIREITOS DOS IMIGRANTES E SERVENTIAS EXTRAJUDICIAIS}

Diante de todo esse contexto visto nos itens anteriores é que chegamos ao seguinte ponto: como a legislação que regula o funcionamento das serventias extrajudiciais, essenciais para a prática de atos relacionados com a cidadania, lida com esses imigrantes de fato, em especial com aqueles em situação irregular?

Já foi apontado anteriormente que os imigrantes de fato são os vulneráveis, os pobres, aqueles que são marginalizados e vistos como mera força de trabalho barato. Esses migrantes são ainda mais vulneráveis quando irregulares, pois se veem totalmente desprotegidos e isolados. Segundo LUSSI:

Pessoas estrangeiras que se encontram em determinadas situações de vulnerabilidade, como é o caso da condição migratória irregular, do isolamento por não conhecimento do idioma ou por formas de exclusão social ou cultural, podem estar mais expostas aos riscos de violações de direitos por causa de suas desigualdades não reconhecidas pelas políticas públicas. (LUSSI, 2015, P. 137)

No mesmo sentido, REIS:

Além da questão dos refugiados e dos problemas que envolvem a reunificação familiar, um dos principais pontos no debate entre a soberania do Estado e os direitos individuais no campo das migrações internacionais concerne ao tratamento dado aos imigrantes indocumentados. Existe muita controvérsia sobre quais são as 
obrigações dos Estados para com os indivíduos que se encontram em situação irregular dentro de seu território. Em termos mais abstratos, trata-se de saber quais são os direitos individuais que devem ser garantidos mesmo aos indivíduos que estão "fora da lei". Muitos Estados temem que uma política que conceda muitos direitos aos indocumentados possa servir como um estímulo para que mais pessoas migrem de forma ilegal. As convenções internacionais têm recomendado que os Estados ajam, sobretudo, no sentido de coibir o emprego de ilegais e as redes internacionais de tráfico de pessoas, e não os imigrantes ilegais em si. Apesar disso a imigração ilegal vem sendo cada vez mais criminalizada na legislação doméstica dos países receptores, com consequências nefastas para todos os imigrantes. [...]

O problema dos indocumentados está no centro de várias polêmicas entre países receptores e emissores. [...]

O estudo da evolução do regime internacional de direitos humanos mostra que é crescente o reconhecimento do indivíduo como portador de direitos independentes de sua nacionalidade, mas, ao mesmo tempo, revela que a implementação desses direitos continua basicamente dependente dos Estados, no caso específico das migrações internacionais, dos Estados receptores. (REIS, 2004, P. 153-154)

A questão do exercício de atos da cidadania através das serventias extrajudiciais está justamente na seara da implementação dos direitos dos estrangeiros, que continua dependente dos Estados, como apontado acima. As normas que regulamentam o uso dos serviços dos cartórios extrajudiciais por imigrantes são, portanto, um bom exemplo de como são as políticas públicas brasileiras em relação a esse segmento da população, por isso a elas é dedicado um item neste trabalho, de forma a comprovar, pelo exemplo, o que se afirmou no item anterior.

Nesse sentido, diversos atos normalmente praticados por cidadãos em serventias extrajudiciais brasileiras são objeto de restrições quando o praticante é estrangeiro. É possível citar, como exemplos: (i) obrigação de comunicação e restrição à aquisição de imóveis rurais 
por estrangeiros (Lei 5.709/71, Decreto 74.965/74, itens 67 a 74 do Capítulo XIV e item 100 do Capítulo XX, ambos das Normas de Serviço dos Cartórios Extrajudiciais da Corregedoria Geral da Justiça de São Paulo - "NGCSP”); (ii) a obrigação de remessa ao Ministério da Justiça de informações sobre casamentos e óbitos de estrangeiros pelas serventias de registro civil de pessoas naturais (item 27.7 do Capítulo XVII das NGCSP); e (iii) necessidade de apresentação de visto válido para prova de identidade para a prática de atos notariais e registrais (item 56 do Capítulo XVII e item 179 do Capítulo XIV, ambos das NGCSP).

Nenhum desses itens mudou com a nova legislação promulgada em 2017, o que só evidencia que, na prática, a efetivação de direitos de imigrantes permanece comprometida, levando à sua marginalização, ainda que se tenha evoluído muito no campo teórico.

Mais vulnerável ainda está o imigrante irregular, que como visto acima não teria condições de praticar qualquer um dos atos mencionados. Aqui se faz especial menção para a falta de condições de comprovar sua própria identificação para a prática de atos simples e importantes na vida de qualquer cidadão, como reconhecimento de firmas, lavratura de escrituras e procurações, reconhecimento de filhos, casamento, etc. Como todos esses atos exigem a prova de identidade, que por sua vez demanda passaporte e visto válido, ao imigrante irregular acaba se tornando impossível praticá-los, o que prejudica sua inserção na sociedade, gerando desigualdade, marginalização e exclusão.

Cumpre mencionar que a segurança jurídica é o cerne da atividade notarial e registral. Particularmente quanto à identificação adequada e segura, há que se esclarecer que é exigida de todos, não apenas do imigrante, justamente por ser essencial para se garantir a segurança na prática dos atos notariais e registrais.

Contudo, em pleno Século XXI, com tantos meios tecnológicos e de integração disponíveis, fica muito difícil defender a impossibilidade de identificação adequada simplesmente pela falta de um visto válido. O requisito essencial para a prática de atos em serventias extrajudiciais é a identificação adequada e com segurança, o que com a tecnologia disponível hoje pode ser viabilizada, desde que sejam providenciadas as normas jurídicas necessárias, bem como acordos necessários entre institutos de identificação de vários países para o compartilhamento de dados ${ }^{2}$.

\footnotetext{
${ }^{2} \mathrm{Na}$ verdade, até em relação aos nacionais esse tipo de regulamentação e integração seria muito bem-vinda e contribuiria para o melhor funcionamento do sistema notarial e registral.
} 
Assim, bastaria uma política pública inclusiva para regulamentar tais situações e viabilizar as integrações necessárias entre institutos de identificação nacionais e internacionais e serventias extrajudiciais.

Ocorre que, na prática, as políticas públicas em geral não tem essa natureza inclusiva, muito pelo contrário. Nessa situação, e sendo a identificação com segurança essencial à prática de atos notariais, o imigrante irregular que não tem condições de cumprir esse requisito fica à margem da sociedade, sem poder praticar atos necessários e básicos ao exercício da cidadania e dos direitos inerentes ao homem.

Aqui, embora se reconheça a necessidade de identificação segura, exigida também, vale dizer, dos nacionais; é preciso que se pense em soluções que possam garantir os direitos dos imigrantes sem comprometimento da segurança do sistema notarial e registral.

Apenas negar esse exercício de direitos sem qualquer solução alternativa, especialmente quando a tecnologia moderna dispõe de soluções satisfatórias nesse quesito, acaba por marginalizar ainda mais os imigrantes irregulares, o que só dificulta sua integração no país receptor.

\section{CONCLUSÃO}

A despeito de toda a evolução teórica e legislativa que o mundo pós-guerra vivenciou, no que tange aos direitos dos imigrantes a verdade é que, na prática, a efetivação desses direitos encontra várias barreiras não apenas no Brasil, mas em todo o mundo. Isso porque a soberania dos Estados permanece inatacável e não há organismo internacional que possa exercer qualquer punição efetiva aqueles que violam direitos inerentes à condição humana, especialmente quando as vítimas não são da nacionalidade do Estado violador.

Assim, o que se vê é que, ainda nos dias de hoje, e mesmo quando há legislação protetora de direitos, a sua efetivação encontra barreiras nos interesses políticos, econômicos e demográficos dos Estados soberanos, que continuam a colocar os "imigrantes de fato" em situações de vulnerabilidade, com marginalizações e até criminalizações, os tratando como um problema de segurança pública e de polícia, quando deveriam ser tratados como sujeitos de direitos. E essa situação é ainda pior quando o imigrante de fato está irregular no país receptor. Nesse sentido, LUSSI: 
$O$ aumento da criminalidade entre migrantes é diretamente proporcional às políticas e práticas que criminalizam social $e$ culturalmente os migrantes e refugiados, o que de fato dificulta sua inserção social e trabalhista, o acesso à moradia com dignidade e a integração na sociedade de destino. [...] Este aspecto da criminalização é estreitamente relacionado com a construção social da imigração como problema de segurança. A criminalização adota o ódio como estratégia social de resistência e não reconhecimento da migração como fenômeno humano. E, enquanto uma dimensão do humano, é um fenômeno socioeconômico, cultural e político, não uma questão penal. (LUSSI, 2015, P. 141)

Mais do que uma evolução legislativa, talvez seja necessária uma evolução cultural, não apenas no Brasil, mas no mundo, de forma a enxergar o imigrante não como um inimigo, mas como um ser humano que precisa ter seus direitos respeitados como qualquer outro.

Com a nova realidade de intensa migração internacional que os Estados soberanos têm enfrentado nos últimos tempos, fica cada vez mais evidente a incongruência entre a visão tradicional sobre migração internacional (que se baseia num viés exclusivamente de direitos de soberania dos Estados e de questões de segurança pública) e os direitos inerentes às pessoas, enquanto seres humanos.

No Brasil, a incongruência fica evidente também pela violação da ordem constitucional, o que se dá não só pelo desrespeito aos direitos dos imigrantes enquanto seres humanos, mas também pela violação da própria lei de imigrações vigente pelo seu próprio decreto regulamentador, e pela vigência de diversas normas esparsas que refletem políticas públicas excludentes. É nesse viés que se incluem as limitações à prática de atos notariais e registrais dentro de serventias extrajudiciais. Atos essenciais para qualquer cidadão e qualquer ser humano, quando restritos ou limitados, refletem a política pública excludente dos imigrantes de fato, em especial os irregulares, que ainda impera em nosso país.

Ainda, a reforçar o argumento da inclusão, o que se aponta é que a criminalização e marginalização de imigrantes não diminui o fluxo migratório, não "protege" um Estado soberano de "invasão" pelos imigrantes em situação de vulnerabilidade, pois não há nada a se fazer nesse sentido, como aponta LUSSI: 
A retórica contra a migração ou a criminalização de migrantes e refugiados não é um processo para terminar com as migrações. Não há nada que se possa fazer para conseguir parar as migrações, a não ser que haja um reordenamento radical da economia mundial. (LUSSI, 2015, P. 142)

Diante dessa realidade inalterável, há que se pensar em formas de lidar com esses imigrantes, de incluí-los e melhor recepciona-los. E tal inclusão, mais do que apenas obediência aos direitos desses imigrantes enquanto seres humanos, permite que uma troca saudável de visões oriundas da diversidade de culturas e experiências possa ocorrer, beneficiando a todos.

Mais do que isso, segundo o Relatório Mundial 2013 da Organização Internacional para as Migrações, há um "reconhecimento cada vez mais generalizado de que a migração canalizada e gerenciada eficazmente pelos encarregados da formulação de políticas pode contribuir ao desenvolvimento". Ou seja, se não por razões humanitárias, a inclusão de imigrantes pode ter um efeito bastante positivo ao Estado receptor, contribuindo para o seu desenvolvimento.

Diante de todo o exposto, fica evidente que a inclusão dos imigrantes não só se coaduna com evolução de todo o estudo sobre direitos humanos iniciado no pós-guerra, como também é, ao contrário do que se poderia pensar, coerente com o mundo globalizado e transnacional do Século XXI; benéfica do ponto de vista cultural e da evolução da civilização humana e, ainda; favorável ao desenvolvimento do Estado receptor. Portanto, quando bem administradas, políticas públicas de inclusão só trazem benefícios à sociedade receptora, razão pela qual a quebra de paradigmas de exclusão se faz necessária e urgente para que a civilização humana possa evoluir e os Estados se desenvolverem nessa nova era.

\section{REFERÊNCIAS}

BONAVIDES, Paulo. Curso de Direito Constitucional. 13. ed. São Paulo: Malheiros, 2003

Convenção Internacional sobre a Protecção dos Direitos de Todos os Trabalhadores Migrantes e dos Membros das suas Famílias, disponível em http://acnudh.org/wp- 
content/uploads/2012/08/Conven\%C3\%A7\%C3\%A3o-Internacional-para-a-Prote\%C3\%A7\% C3\% A3o-dos-Direitos-Humanos-de-todos-os-Trabalhadores-Migrantes-e-Membros-de-suasFam\%C3\%ADlias.pdf., acesso em 29 dec. 2017.

BRASIL, DECRETO No 1.570, DE 13 DE ABRIL DE 1937, disponível em http://www.planalto.gov.br/ccivil_03/decreto/1930-1949/d1570.htm, acesso em 29 dec. 2017.

FERREIRA, Francisco Gilney Bezerra de Carvalho. Direitos e garantias fundamentais - já podemos falar em quarta e quinta dimensões?. Revista Jus Navigandi, ISSN 1518-4862, Teresina, ano 18, n. 3828, 24 dez. 2013. Disponível em: 〈https://jus.com.br/artigos/26078>. Acesso em: 2 jan. 2018.

INSTRUMENTOS INTERNACIONAIS DE PROTEÇÃO DOS DIREITOS HUMANOS, disponível em http://www.pge.sp.gov.br/centrodeestudos/bibliotecavirtual/instrumentos/ sumario.htm, acesso em 29 dec. 2017

LUSSI, Carmem. Políticas públicas e desigualdades na migração e refúgio. Psicologia USP, São Paulo, v. 26, n. 2, p. 136-144, aug. 2015. ISSN 1678-5177. Disponível em: <https://www.revistas.usp.br/psicousp/article/view/102377/100701>. Acesso em: 27 dec. 2017. doi:http://dx.doi.org/10.1590/0103-6564D20140014.

MELLO, Patrícia Campos. Lei de Migração entra em vigor, mas regulamentação é alvo de críticas. Folha de São Paulo, São Paulo, 21 de nov. 2017, disponível no link: http://www1.folha.uol.com.br/cotidiano/2017/11/1936866-lei-de-migracao-entra-em-vigormas-regulamentacao-e-alvo-de-criticas.shtml, acesso em 02 jan. 2018.

NOVELINO, Marcelo. Direito Constitucional. São Paulo: Editora Método, 2009, 3 ed.

PIOVESAN, Flávia. A CONSTITUIÇÃO DE 1988 E INTERNACIONAIS DE PROTEÇÃO DOS DIREITOS HUMANOS, 1997, disponível em http://www.pge.sp.gov.br/centrodeestudos/revistaspge/revista3/rev6.htm, acesso em 29 dec. 2017 
PORTAL TERRA.COM.BR, O que muda com a nova lei de migração. Disponível em https://www.terra.com.br/noticias/brasil/o-que-muda-com-a-nova-lei-de-migracao,b4a7dbe80 ef4c9f6c4f81cb380c84918in0qwjr4. Html, acesso em 04 jan. 2018

REIS, Rossana Rocha. Soberania, Direitos Humanos e Migrações Internacionais. In: Revista Brasileira de Ciências Sociais, vol. 19, n. 55, pp. 149-164, junho/2004.

VELASCO, S. Cidadania, nação e segurança: o imigrante como ameaça à identidade centrada no Estado. In: Imigração na União Europeia: uma leitura crítica a partir do nexo entre securitização, cidadania e identidade transnacional [online]. Campina Grande: EDUEPB, 2014, pp. 23-63. 